\title{
Who is the Strongest in Washington, D.C.?: \\ A Comparative Study on the Korean- American Comfort Women Movement and the Japanese-American Redress Movement
}

\author{
EUNJUNG LIM ${ }^{*}$
}

\begin{abstract}
Washington, D.C. is not only the national capital of the United States, but it is also an international arena in which world political issues are substantially dealt with. Immigrants in the United States represent influence in world politics, exerting their leverage on policy makers in Washington, D.C. The Korean-American Comfort Women Movement in 2007 and the Japanese-American Redress Movement from 1970 to 1992 share common ground in terms of their norms and strategies for success. This article conducts comparative analysis on the two grassroots movements based on Resource Mobilization Theory, and suggests their realistic implications to political dynamics in Washington, D.C.

Keywords: Washington, D.C., Grassroots Politics, Immigrants Group, Resource Mobilization Theory, Comfort Women Movement, Redress Movement
\end{abstract}

\footnotetext{
* Ph.D. Candidate, School of Advanced International Studies, Johns Hopkins University Visiting Fellow, Interfaculty Initiative in Information Studies. The University of Tokyo

E-mail: elim6@jhu.edu
} 


\section{INTRODUCTION}

I $\mathrm{n}$ the context of foreign policy and international relations, Washington,

D.C. is in a league of its own. Its total population of roughly 600,000 and total area of 68.3 square miles may not qualify it as a global city under Sassen (2002)'s definition, but not even New York City is comparable to the scale and magnitude of impact Washington plays internationally. It is for this reason that officials from Japan, for instance, intentionally make regular round trips between Narita and Dulles for official meetings with Capitol Hill and administration personnel, that lasts only one or two days at any one time. South Korean President Lee Myung-bak spent nearly a full week in Washington during his official visit, an indication that world leaders recognize the dividends one reaps by being in this town physically. The ongoing economic recession, the epicenter of which was Wall Strect, has raised questions as to whether the United States is slipping from its status as the preeminent political and economic power in the world; nevertheless, it will remain at least one of the most influential players, with Washington remaining in its unique prominence.

U.S. foreign policy is not confined to high level diplomatic meetings in Washington, D.C. Although the revolving door relationship inherent to this town between lobbyists and elected politicians often involve domestic agenda, many lobbyists also represent international business and government clients as well. In this relatively less-public forum played by occupants of $\mathrm{K}$ Street offices, influential players seek to shape and influence U.S. foreign policy relevant to their areas of interest. An extreme example of this practice is in 1995, when then-Taiwan President Lee Teng-hui hired Cassidy and Associates to pressure the U.S. State Department into reconsidering its initial rejection of a visa request by Lee to travel to Cornell University, his alma mater. Lee's success in playing the $\mathrm{K}$ street game had immediate geopolitical implications. China responded to Washington's U-turn over Lee's visa by launching missile tests and military exercises in the Taiwan Strait, which ultimately lead to the Third Taiwan Straits Crisis (Sheng 2001, 24-28; Ross 2000).

Nevertheless, U.S. foreign policy evolves not only within public official meetings and private lobbyists' interactions. Bottom-up, grassroots movements also have the potential to influence how Washington gets involved in international topics. This article discusses two successful examples of this category: namely the Korean-American Comfort Women Movement in 2007 and the Japanese-American Redress Movement from 1970 to 1992. In presenting the two grassroots movements, the paper serves to examine dynamics of immigrant groups' mobilization in Washington, D.C., and hopes to contribute towards a more holistic understanding of the underlying dynamic forces that influence and shape this city. 


\section{The Cases to be Studied}

"Comfort women" is a euphemistic term for Asian women forced to serve as sex slaves for the Japanese Imperial Army. While the most prominent stories come from the Korean Peninsula and China, Japan has victimized women elsewhere in Asia, such as the Philippines and Indonesia, following its start of a full-scale war in the region in 1937 that eventually escalated into W'orld War II's Pacific Theater in 1941. The full extent of the victimization of these women is difficult to measure; in fact, the issue did not come into the public spotlight even in South Korea until August 1991, when Kim Hak-Sun went public with her story as a comfort woman (Stetz and Oh 2001, 16). Inspired by Kim's courage, former comfort women and civil activists have held "Wednesday Protests" in front of the Japanese Embassy building in Seoul every week since January 8, 1992. Their voices demanding that Tokyo apologize and make appropriate compensations have fell largely on deaf ears for years. However, mobilization of KoreanAmericans in the United States to pass a resolution in the U.S. House of Representatives criticizing the Japanese government on the issue awakened Tokyo in July 2007. forcing it to engage in unsuccessful ad hoc measures such as buying a full-page Washington Post ad that condemned the Comfort Women Movement, as explained in the later section.

However, this is not the only example of grassroots movements influencing international affairs. Twenty years ago, Japanese-Americans succeeded in having the U.S. government apologize for its detainment of 120,000 Japanese-Americans living in the United States mainland into ten concentration camps, which were euphemistically called "relocation centers." Following the shocking attack on Pearl Harbor by Japan in 1941, Franklin Roosevelt issued Executive Order 9066 due to suspicions that Japanese-Americans had been collaborating with their ancestral homeland in the war and hence needed to be locked up in prison camps. While this tragedy remained a taboo among Japanese-Americans for decades, as in the comfort women situation in South Korea, a grassroots movement seeking to redress the issue began in the 1970s. It culminated in 1992 when the U.S. government apologized for the mass lockups and paid $\$ 20,000$ for each of the surviving victims as compensation (Niiya 2001, 120-125; McPhee 2006, 13-16; Daniels et al. 1986, 3-6).

There is a two-decade time lag between these two movements. However, the two movements share several common characteristics for analytical interests. First, both cases are related to compensation issues for World War II victims. Second, the two movements define a specific government as responsible for the victims' plight and sought justice. In other words, both of these mobilizations were bottom-up actions. Third, both movements employed the U.S. legislative system to achieve their goals. Fourth, they are grassroots movements in the sense that respective Foreign Ministries did not mobilize them. Lastly, both 
movements involve Asian-American communities. A comparative analysis of these two cases may lead to a better understanding of how Asian-American groups mobilize to make a political impact in Washington, D.C., and ultimately shape U.S. foreign policy.

\section{Theoretical Framework and Outline of the Article}

Two major theoretical frameworks provide contrasting explanations when analyzing key factors of social movements. On the one hand, classical Collective Behavior Theory (CBT) characterizes social movements as emotional, impulsive, and unorganized phenomena based on unpredictable mass enthusiasm (Morris 2000). Resource Mobilization Theory (RMT), on the other hand, recognizes social movements and movement participants as political, well-planned, and organized. Morris's (1992) explanation on the American Civil Rights Movement, for instance, is analytically relevant to the study conducted in this article. Morris suggests that the RMT Model fits the analysis of the Civil Rights Movement, and he concludes that collective action is rational and it develops from preexisting social structures and political processes.

RMT is useful especially when investigating the abilities of groups to organize, mobilize, and manage the necessary resources for success of a movement. As Morris (1984) states, RMT illuminates the importance and necessity of the resources to initiate and develop any social movement. The resources include formal or informal organizations, leaders, money, people, and the community's network. RMT does not focus on governance, psychic strain, and other psychological states of members who participated in a movement for its analysis. Instead, the theory mainly analyzes the ability of groups to organize, mobilize, and manage valuable resources that determine whether they will be able to engage in social protest.

This study aims to generalize the norms and strategies of the two grassroots movements in the United States. In doing so, it hopes to distill key factors that make such mobilizations successful, irrespective of issue, time, or ethnicity. From that perspective, it can be expected that institutional features of both the Korean-American Comfort Women Movement and the Japanese-American Redress Movement can be explained more concretely through the theoretical framework of RMT rather than through CBT.

The first section will review how the Comfort Women Movement succeeded in the passage of the House Resolution 121 (H. Res. 121) in July 2007. It will shed light on how Korean-Americans mobilized its community both regionally and nationally, utilized media to spread their message, and found sympathizers inside Capitol Hill. The second section will review the physical mechanics that ultimately led to the Japanese-Americans' success in their Redress Movement. The concluding section will outline similarities of the two movements, and the 
influence of such movements in the political sphere of Washington, D.C.

\section{THE KOREAN-AMERICANS' COMFORT WOMEN MOVEMENT}

In understanding regional politics within Northeast Asia, historical legacies and differing interpretations of the World War Il-era are unavoidable. A specific example is Japan's policy of acknowledging its wartime wrongdoings, but reluctant to formally apologize for them. Tokyo has refused to change its position despite repeated overtures at official levels and long-standing, persistent efforts by surviving comfort women victims. What complicates Seoul's position in changing Tokyo's stance is the growing interdependence elsewhere between the two countries (Green 2001, 134-7). It is against this geopolitical backdrop that Washington finds itself in a unique position over addressing this historical issue.

Despite Japan enjoying a unique security alliance with the United States, H. Res. 121 would officially force the United States to voice its demands that Japan settle accounts with its neighbors. It states that the Japanese government should formally acknowledge, officially apologize, publicly take historical responsibility for coercing Asian women into sexual slavery during World War II, and educate current and future generations about this tragedy. The passage of $\mathrm{H}$. Res. 121 is a historic achievement in which the Korean-American community mobilized in an unprecedented scale, that caused a geopolitical earthquake that Seoul and other Asian governments have long sought unsuccessfully.

\section{Chronological Summary of the Comfort Women Movement}

The journey of $\mathrm{H}$. Res. 121 began exactly ten years ago from its passage, namely in July 1997 when William Lipinski (D-IL 3rd) introduced H. Res. 126, which urged the Japanese government to formally apologize and compensate the victims of war crimes that were committed by the Japanese military during WWII. In June 2000, Lane Evans (D-IL 17th) and thirty other House Representatives introduced a similar resolution, H. Con. Res. 357. Following this progress, fifteen former comfort women from South Korea, Taiwan, and the Philippines filed a lawsuit in the U.S. District Court in Washington, D.C., which was the first time the "comfort women" issue was treated in the U.S. Courts. Also, it was the first time that Japan was appointed as defendant. Evans committed himself to the comfort women issue by introducing consecutively $\mathrm{H}$. Con. Res. 226 in June 2003 and H. Res. 759, which was a bipartisan measure with Christopher Smith (R-NJ 4th), in February 2006 (Washington Coalition for Comfort Women Issues (WCCW)).

Even though H. Res. 759 was unanimously approved at the then-House International Relations Committee (since renamed House Foreign Affairs Committee) 
on September 12, 2006, it was not accepted at the 109th Congress. However, momentum did not die with the end of 109th Congress. On January 31, 2007, a bipartisan group of seven Representatives including Mike Honda (D-CA 15th) and Frank Wolf (R-VA 10th) introduced H. Res. 121. The following day, the Korean American Voters' Council (KAVC) mailed letters to Korean-Americans, urging their cooperation for the passage of H. Res. 121. KAVC also began a nationwide petition campaigning to get the attention of lawmakers. I W/ithin only a week, the KAVC succeeded in obtaining signatures from more than 8,000 people. Grassroots momentum encouraged Tom Lantos (D-CA 12th), the then-Chairman of the House Foreign Affairs Committee, to hold the first full committee hearing on "comfort women" before the House Foreign Affairs Committee on February 15. This public hearing was broadcasted through the United States by The American Broadcasting Company, The New York Times, and The Washington Post (Kim 2007c). However, even this quick movement at the grassroots and legislative level may have not led to the same results if not for a geopolitical gaffe.

On March 1, then-Japanese Prime Minister Abe Shinzo commented that he did not think the Japanese military had coerced Asian women into serving as comfort women during World War II. Hence, Abe said he would not apologize even thought he regretted their plight (Onishi 2007). The Premier's comment caused an explosive reaction overseas, especially in South Korea, because the remarks were made on the same day of the largest independence movement that took place in 1919 against Japan's colonization of the Korean Peninsula. Abe's shockwave spread across the Pacific, mobilizing not just the ethnic Korean-American groups, but mainstream U.S. media, including The New York Times, The Los Angeles Times, and The Washington Post ("No Comfort" 2007; "Shinzo Abe's Double Talk" 2007; "The Truth about Japan's 'Comfort Women"” 2007).

Riding on the wave of sympathetic public opinion, those interested in the issue coalesced nationally, beginning with New York City, Washington, D.C., Philadelphia, Los Angeles, and San Francisco. The number of regional coalitions for this particular issue reached nineteen. These regional coalitions began lobbying at Capitol Hill from March 12, and they attained signatures in support of $\mathrm{H}$. Res. 121 from seven Representatives on the same day. H. Res. 121 increasingly gained endorsements since its introduction, and the number of legislators who signed onboard as co-sponsors reached fifty four on March 21 (Kim 2007c).

The momentum that began early during the 110th Congress took itself to a new level in April with a series of media blitz. On April 17, 2007, a KoreanAmerican filmmaker and civil rights activist Annabel Park uploaded a video onto Youtube ${ }^{2}$ that included victims' testimonies and pleas for $\mathrm{H}$. Res. 121's passage. In addition, Korean-American coalitions on the comfort women issue greeted Prime Minister Abe's Washington visit on April 25 with their own 
full-page Washington Post ad entitled "The Truth about 'Comfort Women.'” During Abe's visit, Korean-American groups visited Capitol Hill and finally succeeded in obtaining the support of one hundred Representatives (Kim 2007c). By the time sixty three Japanese leaders, mainly comprising of nationalistic Diet members, responded with their own Washington Post full-page ad, "The Fact," on June 14 of the same year (Asian Policy Point 2007), it was too late to change U.S. pubilic opinion on the issue.

The Korean-American groups succeeded in getting support from 143 Representatives by June 7, and H. Res. 121 was approved by 39 to 2 at the House Foreign Affairs Committee on July 26 (Kim 2007c). The number of co-sponsors had grown up to 168 in July, and finally the U.S. House of Representatives approved H. Res. 121 by a voice vote on July 30, 2007 (Ryu 2007).

\section{Keys to the Success}

At the holistic level, the Comfort Women Movement began its initiative by informing its audience that they were not on a parochial mission, but a national one. The participants stressed that neither the South Korean people nor government were assisting or guiding their actions. They instead said that they were engaged in an authentically American movement in the American way, in the spirit of indigenously American values such as human rights, women's rights, and justice. Their consistent message on "American" values throughout the H. Res. 121 process led them to state repeatedly that the legislation does not intend to adversely impact the geopolitics of East Asia. Secondly, they promoted this cause not as a Korean-American one, but of an American one as a whole. The participants argued that the request from American citizens should not be discouraged by Japanese lobbying. Third, they also argued that $\mathrm{H}$. Res, 121 would eventually be conducive to improving alliances between the United States and other Asian countries, including Japan, by restoring intricate relationships among the regional members. Fourth, they took a bipartisan approach in seeking H. Res. 121's passage. ${ }^{3}$ In steering away from a parochial message, the coalition established a foundation on sound ideology.

Nevertheless, RMT theory reveals that the normative approach the KoreanAmerican groups employed was not the only source of the extraordinary success in 2007. First and foremost, the Korean-American groups were equipped with organizational capability. The New York/New Jersey-based KAVC played a key role in planning strategies, organizing the nineteen regional coalitions nation-wide, mobilizing Korean-Americans, and fund-raising and lobbying in Washington. In addition to the KAVC's broad national framework, the regional coalitions on the comfort women issue brought together concerned people in nineteen regions across the country. These organizations as well as other activists used community forums such as Korean churches and associations to promote 
and spread the cause. ${ }^{4}$

Specific individual leaders can be identified as the next factor towards the 2007 success. In addition to Annabel Park mentioned above, key leaders include the Executive Director of the KAVC Dong-suk Kim, President of the Washington Coalition of Comfort Women Issue Ok-cha Soh, Co-chair of the Washington Coalition Moon-hyung Lee, and In-Hoe Huh, a Korean politician who actively confronted his home country's military dictatorship during the 1980s.5 As Morris (2000) suggests, these leaders of diverse backgrounds forged a unique leadership that contributed to a broad mobilization and networking of all Korean-Americans. They also shared their abundant experiences in social movements in guiding the Comfort Women Movement towards a single, viable path.

What may be the most interesting factor towards their success in passing H. Res.121 may be the Korean-American groups' tactics. Tactical solutions enormously influence how social movements develop (Morris 2000). The methodologies of the participants of the Comfort Women Movement can be characterized by the following features.

First, the Korean-American groups made intelligent use of their resources by appealing to key members of the House of Representatives first, not to all 435 of them. Evans was such a precursor before H. Res. 121 took shape as stated above. For example, Lantos was the powerful chairman of the House Foreign Affairs Committee, who had survived the Nazi Holocaust and hence prioritized a human rights agenda throughout his House career (Kim 2007a). Wolf had strong convictions and interests in both East Asia, as well as human rights. Tom Davis (R-VA 11th), a Virginian Republican representing a Washington suburb district, was another such supporter. He said that true friends should be able to candidly criticize a friend's wrongdoing without harming their friendship. Nancy Pelosi (D-CA 8th) and Lynn Woolsey (D-CA 6th), two female Californian Democrats, are strong believers in women's rights. ${ }^{6}$

In addition to seeking support of issue-specific legislators, the Korean-American groups also appealed to members interested in their local constituencies. Honda is one interesting example. Honda is a Japanese-American whose family had experienced the internment camps during World War II, and the tragic legacy during his childhood raised Honda as a confident pacifist. More interestingly, his district is rich in ethnic diversity including a substantial number of Koreans and Chinese (Honda, Official Website). As such, it can be said that he skillfully molded his personal and professional interest towards introducing and consistently supporting H. Res. 121. Also, Korean-Americans in Los Angeles invited Lantos, another California lawmaker and the key person for the passage of $\mathrm{H}$. Res. 121, to their gathering on June 16, 2007. Lantos promised his support for H. Res. 121 at the meeting with the L.A. Coalition on the same day (Kim 2007c). The Korean-American groups allied with such key individual legislators to lead the bipartisan House leadership towards this initiative. 
Second, the Korean-American groups expanded their Congressional support by traditional outreach. Ethnic Korean-Americans actively visited both Washington, D.C. and local offices of representatives who were initially not on board with H. Res. 121. For example, the now Asia Pacific Committee Chairman Don Manzullo (R-IL 16th) doubted whether the U.S. House of Representatives should be involved in the comfort women issue at the beginning of the movement (Kim 2007c). He switched his initial opposition to H. Res. 121 following visits by Korean-Americans to his office. In total, Korean-American groups held Lobby Days twelve times to visit members' offices in Washington, D.C.?

Third, the Korean-American groups labored to maximize media impact. They had held fund-raising campaigns and used approximately $\$ 50,000$ for a full-page ad in The Washington Post, a national newspaper with a specific focus on the Washington and Virginia area $(\mathrm{Kim} 2007 \mathrm{c})$. Furthermore, they purchased a full-page ad on The Hill, a daily newspaper about Capitol Hill, read by the media and government professionals such as Congressional staffers interested in U.S. Congress. They used the letter from Jan Ruff-O'Herne, an Australian comfort women victim, to then-House Speaker Nancy Pelosi. The fact that Australians were victims to past Japanese aggression caught the audience's attention. $\mathrm{x}$ The Korean-American groups also employed social media such as Youtube. Park's use of English narrators as well as popular Korean celebrities is said to have appealed to a broader audience than in previous outreaches (Park 2007).

Fourth, the Korean-American groups worked to diversify their base and sought to paint their movement as a typical minority group social movement in the United States. For example, they cooperated with other immigrant groups such as those of Chinese and Filipino descent. They even worked with non-governmental organizations in Japan as well. With Asia Policy Point, those Japanese groups collected and provided evidence of comfort women in preparing for the February 15, 2007 public hearing before the House Foreign Affairs Committee (Dong-suk $\mathrm{Kim}$, personal communication, May 22, 2009; Kim 2007c). They also won the help of Amnesty International, which contributed to reducing the cost of the full-page ad in The Washington Post." Despite efforts to broaden their support, they did not want to internationalize the cause, and asked the South Korean Embassy in Washington and the South Korean National Assembly to refrain from participating. Fearing backlash of foreign-backed support, Korean-Americans strove to diversify their support only within the civilian level, not beyond (In-hoe Huh, personal communication, September 24, 2007; Kim 2007c).

Interestingly, the tactics and approach Korean-Americans employed is largely consistent with observations once made by former Senator John C. Danforth (R-MO) about grassroots legislative support mechanisms. The former Missouri lawmaker observed that the most successful forms of political campaigns to mobilize Congress are letter-writing or newspaper ad campaigns (Hrebenar 1997, 
157). The Comfort Women Movement utilized both forms of these campaigns, which caught the attention of the legislative branch. In that sense, it would be fair to conclude that the Korean-American Comfort Women Movement in 2007 was well-equipped with what RMT emphasizes. The movement participants were armed with appropriate norms and used effective tactics of winning public opinion both inside and outside Capitol Hill. The KAVC's strategic headquarters and the Comfort Women Movement's organizational capability produced a well-coordinated and intelligent campaign that produced a different outcome in 2007 as contrast to the past.

\section{THE JAPANESE-AMERICAN REDRESS MOVEMENT}

The Japanese-American Redress Movement that occurred a few decades prior to the passage of H. Res. 121 is seen as an example of a successful social movement in modern U.S. history. Historically speaking, this is the first time a major policy decision has fell in favor of Asian-American immigrants since the first Asians migrated to the United States in the late nineteenth century. The movement first began in 1970 when the Japanese American Citizens League (JACL) began to show its interests in the issue. The grassroots movement evolved into a political agenda by members of Congress of Japanese descent. Partly due to the relatively longer history of the Japanese-American case, it was also built on historical precedent, such as the 1943 Supreme Court rulings of Yasui v. United States and Hirabayashi v. United States, as well as the 1944 ruling of Korematsu v. United States. Moreover, the redress movement involved the U.S. president himself, with Jimmy Carter, Ronald Reagan, and George H. W. Bush all having played roles.

Because much literature is written about the Japanese-American movement itself, this article seeks to not talk about the movement, but to draw RMT framework-based conclusions about immigrant groups in the United States using it as one example. Therefore, the emphasis should be laid on the early stages

of the Japanese-American Redress Movement, from 1979 to 1980, even if the latter stages, such as when victory was finally achieved in 1992, are still covered.

\section{Chronological Review of the Japanese-American Redress Movement}

Interestingly, the JACL was not enthusiastic about engaging in the Redress Movement at its onset. In fact, the issue was a controversial one that was a source of confrontation between the advocates and JACL members. In the late 1960 s, small groups of Japanese-Americans in the West Coast, including Southern California, San Francisco, and the Seattle areas, began to move on the redress issue (Daniels et al. 1986, 188). At the time, JACL leaders felt that it was 
a taboo subject among Japanese-American people. They feared it would create fissures within the JACL and stayed largely inactive until July 1970 (Takezawa 1995, 38). At a National Convention during that month, the JACL finally approved its first resolution recognizing the topic as the organization's key concern. In the next National Convention in 1974, the JACL established a National Redress Committee. In 1978, at another National Convention that Salt Lake City hosted, members approved for the Committee and unanimously adopted the redress issue as its top agenda (Daniels et al. 1986, 191-2).

It was young Asian-American leaders who made 1978 a breakthrough year in the cause. Led by a third-generation Japanese-American actor Frank Abe and Chinese-American playwright Frank Chiu, they suggested that the forced relocation of Japanese-Americans be reenacted during the Day of Remembrance. That active initiative mobilized more than two thousand campaign participants on November 25, 1978 and helped the Japanese-American community to finally begin breaking their silence. Support for the issue continuously increased among Japanese-Americans since then (Takezawa 1995, 42-5).

On February 1, 1979, the JACL took action to a new level by reaching out to Japanese-American members of Congress. The National Redress Committee held meetings that day with Hawaii Democrat Senators Daniel Inouye and Spark Matsunaga, as well as California Democrat Congressmen Norman Mineta and Robert Matsui about their plans and strategies to make the redress movement successful. Legislators advised the JACL committee that "to convince the American public and the members of Congress of the injustice it was necessary to establish an official determination of wrong action by the government before advancing reparation legislation" (Takazawa 1995, 47). That was the beginning of a series of legislative actions that would last for years.

A bipartisan group led by Senators Inouye and Matsunaga introduced S. 1647 on August 7 of the same year. Called the Commission on Wartime Relocation and Interment of Civilians (CWRIC) Act, it called for a creation of a federal commission to investigate the facts behind the forced wartime relocation. Furthermore, nine Democrats introduced H. R. 5499, the House companion bill to S. 1647, with over 110 co-sponsors on September 28, 1979. Exactly two months after H. R. 5499 was introduced, Washington Democrat Mike Lowry introduced H. R. 5977 . Called the Japanese-American Human Rights Violation Redress Act, it requested compensation of $\$ 15,000$ for each internee at a rate of $\$ 15$ for each day in the camp. The Senate overwhelmingly passed S. 1647 on May 1980 and the House of Representatives passed H. R. 5499 by 297 to 109 on July 21, 1980. The CWRIC finally became law when President Carter signed the legislation ten days later, on July 31 (Daniels et al. 1986, 193; Hatamiya 1993, 84-8).

As the CWRIC authorized a federal commission, the three former petitioners during World War II, Fred Korematsu, Minoru Yasui, and Gordon Hirabayashi, each filed a petition for writ of error coram nobis to reopen their wartime cases 
in January 1983. The CWRIC published a report on the cases, entitled "Personal Justice Denied" on February 24, 1983, and the commission proposed its recommendations for remedies due to the wartime violation of constitutional rights in June 1983. A Texas Democrat Jim Wright introduced the H. R. 4110 on October 1983, which called for acceptance and implementation of the CWRIC's findings and recommendations. U.S. District Court Judge Marilyn Patel granted Korematsu's petition for a writ of error coram norbis, vacating his 40-year-old convictions on November 10, 1983 (Daniels et al. 1986, 200-202).

New leadership following the 1986 midterm elections accelerated the Redress Movement. H. R. 4110, which died in the House when the Congressional session ended in 1984, was re-introduced by House Majority Leader Tom Foley as H. R. 4110. Entitled the Civil Liberties Act of 1988, this initiative by the Washington Democrat gained with 124 co-sponsors when it was presented on January 6, 1987. Matsunaga introduced S. 1009, the Senate version of H. R. 442, with 71 co-sponsors. On September 17, the bicentennial of the U.S. Constitution, the House passed H. R. 442 with 243 to 141. The senate followed suit on April 20, 1988 by passing its version 69 to 27. The legislation finally became law on August 10, 1988, with President Reagan's signature. Reagan's successor, George H. W. Bush, approved the compensation in 1992 (Daniels et al. 1986, 219-223).

\section{Keys to the Success}

What were the keys to the Japanese-Americans' triumph in 1992? Almost foreshadowing the 2007 actions by the Korean-Americans, the Japanese-Americans also presented their cause not as a parochial, but national issue that transcended ethnic divides. They emphasized that the movement was based on American values of freedom and justice. Dr. Clifford I. Uyeda, who took the struggle within the JACL, proposed to the JACL that they link the Japanese-Americans' tragedy with the Nazi Holocaust. The JACL Redress Committee agreed with his idea and subsequently indicated that redress for the injustices of 1942-1946 was not an exclusive issue of Japanese-Americans, but a concern for all Americans. While it did not say that financial restitution would close the issue completely, the statement noted that acknowledging past mistakes fully would prevent a repeat of such injustices in the future (Daniels et al. 1986, 189). As in the Comfort Women Movement, the "American values" contended by the Redress Movement participants provided them with an ideologically firm ground to persuade their audience, both the lawmakers and the general public nationally.

Secondly, the JACL's role as the key organization that led the bottom-up movement, almost parallels the role the KAVC played three decades later. In fact, the JACL was the first Asian-American civil rights organization of its kind when it was founded in 1929. Although the JACL was reluctant to engage in the Redress Movement in the early stage, it used its organization's full weight 
following July 1970 to lead the grassroots movement towards mobilizing, networking, and organizing people interested in the issue.

Thirdly, leadership also played a significant role in the movement. Younger Japanese-American leaders who did not necessarily experience the internment took original initiatives to raise awareness of the redress issue. Their cause was helped by the fact that some Japanese-American politicians were already serving in the highest levels of government. The legislative experience and networks that legislators such as Inouye and Matsunaga provided shaped effective strategies towards addressing relevant legislations. In retrospect, it may even be logical to argue that links to Capitol Hill gave the Redress Movement an easier journey than that of H. Res. 121 in the twenty-first century.

Fourthly, it is necessary to summarize tactical solutions of the Redress Movement participants. In order to approach politicians in Washington, D.C., their first target was, of course, the Japanese-American members of both Houses of Congress. Having gained their support, they turned to Senators and Representatives from the West Coast. Although Asian-Americans were only $2.5 \%$ of the country in 1985, their influence was significantly higher in the West Coast (Hatamiya 1993, 147). For example, Don Toshiaki Nakanishi mentioned that Representative Lowry had recognized electoral support from Japanese-American groups in his election, and prompted him to introduce the first Japanese-American reparations bill in the House in 1979 subsequently after his election (Rich 1996, 103).

In regard to justification to persuade politicians in Washington, D.C., there could be varied explanations. Hatamiya $(1993,153)$ explains that some politicians were persuaded by personal connections to Japanese-American politicians such as Senator Matsunaga or Representatives Mineta and Matsui, while others advocated the issue on ideological norms. In spite of the different origins, it is still the case that the legislators with no Japanese heritage needed to be convinced directly by the Redress Movement. Hence, they could not narrow their audience, but instead needed to expand the issue's appeal across the country by reaching out to the American people as a whole. The final "linchpin of the strategy to win passage of HR 442 in 1987" was to get commitment from a wider range of congressional districts (Hatamiya 1993, 155).

In brief, it can be concluded that the Redress Movement participants worked systematically to persuade politicians and the American public through American ideological values and the power of local constituency. The organizational capability of the JACL in mobilizing their voting power and grassroots lobbying made the Redress Movement coherent toward its successful end.

\section{CONCLUSION}

Close examination of the social movements that Japanese-Americans and Korean-Americans mobilized in the twentieth and twenty-first century, re- 
spectively, shows that they generally follow what RMT emphasizes. In this concluding section three major similarities of the two movements will be proposed. Further questions and implications for the political reality in Washington, D.C. will be suggested in the end.

\section{Similarities between the Two Movements}

The first similarity is that both movements appealed to a broader audience beyond their immediate constituency with comprehensive ideals. Both Americans of Korean and Japanese descent continuously contended that their movements were not for exclusive interests of some specific groups or countries, but that they were for general values such as human rights and equal justice that all American people champion. This ideological rationale played a crucial role in establishing a normative foundation for both movements and gained support of politicians and the general public nationwide.

The second similarity is that the participants of the Comfort Women Movement and the Redress Movement had strategic headquarters and were mobilized nationally. Both the KAVC and the JACI. collaborated with preexisting communities such as churches and local network associations. The three largest cities where Korean-Americans mainly reside, Washington, New York, and Los Angeles, were the bridgehead across the nation for networking Korean-Americans. In the case of the Redress Movement, West Coast States such as Washington and California were the cradle of the movement. These nationally-mobilized groups that had risen up in these primary areas eventually succeeded in leveraging politicians in Washington, D.C.

What may be the most revealing similarity is that both movements approached American politicians based on bipartisanism and local constituency. Former Illinois Republican Congressman Thomas Raisback's remark explains how the two movements succeeded in persuading American politicians: "the most effective lobby campaign involve local constituency. $\cdots$ If you get a letter from a constituent, you pay attention. He is not an outsider. He is somebody who votes for or against you" (Hrebenar 1997, 157; emphasis added). The two cases in this article prove that grassroots lobbying can be "100 percent more effective than professional lobbying" in Washington, D.C., as former California Democrat Representative Jerome R. Waldie also confessed (157).

All of these three common features between the two movements match with what RMT highlights when explaining how social movements can be successful. Also, the two movements prove that social movements are rational and organized with political purposes by contrast to what CBT perceives.

\section{Further Questions and Contemporary Implications}

Much remains to be seen about the Korean-American movement as it is still 
a nascent case compared to the Japanese-American initiative. For example, further studies should be made on why Korean-Americans could be mobilized on a historical issue relating to events seven decades back, and why this was the first successful mobilization. This difference is consequential in that unlike the Redress Movement, the Korean-Americans involved were neither victims nor were they seeking for Washington to pressure Tokyo for compensation. In fact, Korean-Americans were not publicly calling for concrete diplomacy, which imply that they were not expecting actual results. If they did not expect measurable results from their actions, it might raise the question of whether Korean-American participants acted rationally. If it can be concluded that they were rational, then further studies need to show what rationale or motivation drove their collective behavior. Could it be that Korean nationalism remains strong among Korean-Americans? Regarding these inquiries, it is without a doubt that Americans of Korean descent became organized and mobilized nationally for the first time over a political initiative in 2007.

An interesting finding among the two cases is that of the Sansei, third generation Japanese-Americans, who were more enthusiastic in the Redress issue while younger Korean-Americans such as Annabel Park took the initiative in the Comfort Women Movement. The fact that both Frank Abe and Park have been in the filmmaking industry could suggest that the younger generation had both the energy and the skills to mobilize the public over a cause. That may contrast with their preceding generations, who may have just emigrated from their home countries and were preoccupied with finding a stable livelihood in their new homeland. Because the older generation had laid a stable foundation through their sacrifices, younger generations may have had the luxury as well as to be inclined to pursue their national identity and express their ancestral heritage. Furcher studies may reveal that Korean-American society has finally reached this stage in the first decade of the twenty-first century, as the Japanese-American society had done so before them in the 1970s. Although Korean-Americans do not have elected national legislators, they reached the same destination as the Japanese-Americans in that both ultimately formulated their collective will and influenced American politicians with their voting power. In this sense, it is fair to conclude that the participants of the Comfort Women Movement acted rationally in order to receive their political gain, and they were well integrated in their situation.

The next question would be the future development of the Comfort Women Movement and the Korean-American community's activities in American politics. Japanese-Americans eventually became self-confident when they succeeded in the Redress Movement. William Hohri vigorously appraised this by saying, "we are placing the issues of exclusion and detention squarely before the bar of justice and the bar of history." His chapter title "Redress as a Movement towards Enfranchisement" also implies that Japanese-Americans would move forward 
to empowering their political voice in the United States (Daniels et al. 1986, 199). This will likely be remembered as what Morris (2000) described as the "transformative event."

This would be the same for the Korean-American community as well. Korean-American leaders did not end their political initiatives with $\mathrm{H}$. Res. 121. Dong-suk Kim and the KAVC worked on what was called "Come from the Shadows: Comfort Women," which opened at the Kupferberg Holocaust Resource Center and Archives in New York on August 15, 2011, Korean Independence Day. Kim also tried to arrange meetings between Korean comfort women survivors and Holocaust survivors in the United States. Working with Jewish-Americans appeared to be raising the possibility of providing an educational program that included the comfort women issue in American public schools. On the other hand, Park took another direction. Following the July 2007 passage, she subsequently participated in the "9500 Liberty" project, which advocates rights of immigrants, particularly Mexican immigrants in Northern Virginia, 10 It remains to be seen whether Korean-Americans would pursue their cause in the near future or work across ethnic lines over a common cause in political freedom and civil liberties.

While proponents of $\mathrm{H}$. Res. 121 claimed that they were not looking to disturb geopolitical dynamics, geopolitical shockwaves continued to reverberate. With the Dutch Parliament's prompt initiative in response to the passage of H. Res. 121, the European Union Parliament also passed its own resolution on the comfort women issue in December 2007 (Keum 2007; "EU Parliament Passes Resolution on Comfort Women" 2007). Moreover, the South Korean Constitutional Court decided on August 30, 2011 that it is unconstitutional for the South Korean government to not pursue all diplomatic means to have the Japanese government provide proper compensation for Korean victims of sex slavery in World War II (Kim 2011). Following the ruling, the South Korean Ministry of Foreign Affairs and Trade officially proposed setting up bilateral consultation with Tokyo to discuss claims to Japan on addressing the needs of comfort women and atomic bomb victims as well as Sakhalin Koreans. It was the first time for the South Korean government to suggest a South Korea-Japan bilateral meeting on the related issues (Roh 2011). In addition, Dong-ik Shin, Deputy Permanent Representative of the Republic of Korea to the United Nations, expressed deep concerns over the "comfort women" problems and reemphasized the necessity of preventing this kind of tragedy at the 66th Session of the UN General Assembly on October 11, 2011. It was also the first time since 1997 that the South Korean government addressed the issue of comfort women at the General Assembly (Son 2011).

It can be said that long-term geopolitical effects continue to be felt from actions that took place inside the United States that culminated in a cornerstone decision inside Washington, D.C. Compared to the Comfort Women Movement, 
the Japanese-Americans' Redress Movement did not directly impact foreign relations including the U.S.-Japan relationship because the scope of compensability was limited within the United States. However, the legacy of the Redress Movement cannot be underestimated. The Redress Movement lit a torch in the history of Asian-American social movements.

As stated in the beginning, Washington, D.C. is in a league of its own on foreign policy and international affairs. Many heads of states, lawmakers, and international affairs professionals, aware of this reality, have repeatedly visited, worked, or even lived in this town. However, it is not only they or the $\mathrm{K}$ Street lawyers representing them that lead to key shifts in U.S. foreign policy. An upsurge of bottom-up citizens' movements addressing an issue with international implications can influence decision-making in U.S. foreign policy that can reverberate well beyond the two oceans that traditionally provided a geographical barrier to the world's oldest living democracy. Disregard or denial that such grassroots movements exist could mean an inaccurate understanding of the political dynamics of Washington, D.C., with likewise international consequences.

\section{REFERENCES}

Asia Policy Point. Accessed November 1, 2011. hetp://www.jiaponline.org.

Asia Policy Point. 2007. Signatories to the June 14th Washington Post "The Facts' Advertisement. July 25. Accessed November 2, 2011. http://www.jiaponline.org/documents/Jun 14AdALLSignatoriesLIST.pdf.

Bauer, R. A., I. de S. Pool, and L. A. Dexter. 2007. American Business and Public Policy: The Politics of Foreign Trade. New Brunswick, NJ: Aldine Transaction.

Baumann, F. E., ed. 1982. Human Rights and American Foreign Policy. Gambier, $\mathrm{OH}$ : Public Affairs Conference Center, Kenyon College.

Brooks, R. L. 1999. When Sorry Isn't Enough: The Controversy over Apologies and Reparations for Human Injustice. New York: New York University Press.

Daniels, R., S. C. Taylor, and H. H. L. Kitano, eds. 1986. Japanese Americans: From Relocation to Redress. Salt Lake City, UT: University of Utah Press. EU Parliament Passes Resolution on Comfort Women. 2007. The Korea Times. December 14. Accessed October 28, 2011. http://m.koreatimes.co.kr/www/ news/nation/2011/10/205_15552.html.

Festen, M. and M. Philbin. 2007. Level Best: How Small and Grassroots Nonprofits Can Tackle Evaluation and Talk Results. San Francisco, California: Jossey-Bass. Fisher, D. R. 2006. Activism, Inc.: How the Outsourcing of Grassroots Campaigns Is Strangling Progressive Politics in America Stanford, CA: Stanford University Press.

Gillmor, D. 2004. We the Media: Grassroots Journalism by the People, for 
the People. Sebastopol, CA: O'Reilly Media.

Green, M. J. 2001. Japan's Reluctant Realism: Foreign Policy Challenges in an Era of Uncertain Power. New York: Palgrave.

Hart, S. 2001. Cultural Dilemmas of Progressive Politics: Styles of Engagement among Grassroots Activists. Chicago, IL: The University of Chicago Press.

Hatamiya, L. T. 1993. Righting a Wrong: Japanese Americans and the Passage of the Civil Liberties Act of 1988. Stanford, CA: Stanford University Press. Hohri, W. M. 1988. Repairing America: An Account of the Movement for Japanese-American Redress. Pullman, WA: Washington State University Press. Honda, M. Official Website. Accessed October 29, 2011. http://honda.house.gov/. Hosokawa, B. 1982. JACL in Quest of Justice. New York: W. Morrow.

Hrebenar, R. J. 1997. Interest Group Politics in America. Armonk, NY: M. E. Sharpe.

Japanese American Citizens' League. 1945. The Case for the Nisei. Salt Lake City: The Japanese American Citizens' League.

Japanese American Citizens League. Accessed August 31, 2011. http://www.jacl. org.

The Comfort Women Issue. Japanese Embassy in the United States. Accessed August 28, 2011. hetp://www. us.emb-japan.go.jp/english/html/cw1.htm.

Keum, D.-G. 2007. The Lower House of the Dutch Parliament Passes Resolution Urging Japan to Apologize and Compensate to Comfort Women. The Dong-A Daily. November 12. Translated by the author. Last modified September 26, 2009. Accessed September 1, 2011. http://news.donga.com/3//20071112/8510 $664 / 1$.

Kim, D.-S, 2007a. The Number of Co-sponsors for H. Res. 121 Exceeds 110: Attention to Tom Lantos Who Holds the Key. Column. Views and News. May 18. Translated by the author. Accessed October 16, 2011. http://www.view snnews.com/article/view.jsp?'seq $=15637$.

Kim, D.-S. 2007b. "H. Res. 121 Is Likely to Be Passed on 26th, Promised by Lantos." Column. Views and News. June 19. Translated by the author. Accessed October 16, 2011. http://www.viewsnnews.com/article/view.jsp? seq $=17471$.

Kim, D.-S. 2007c. (Interview by Kim Hong-kuk). We, Korean Americans, Overcame Japan As Like This. Views and News. July 7. Translated by the author. Accessed October 16, 2011. http://www.viewsnnews.com/article/view. jsp?seq $=18090$.

Kim, R. 2011. Slack Gov't Effort for Comfort Women Unconstitutional. The Korea Times. August 30. Accessed October 15, 2011. http://www.koreatimes.co. $\mathrm{kr} / \mathrm{www} / \mathrm{news} / \mathrm{nation} / 2011 / 08 / 117$ _93791.html.

Kingdon, J. W. 1973. Congressmen's Voting Decisions. New York: Harper and Row.

Kingdon, J. W. 1999. America the Unusual. New York: Worth Publisher. 
Kitano, H. H. L. and R. Daniels. 1995. Asian Americans: Emerging Minorities. $2^{\text {nd }}$ ed. Englewood Cliffs, NJ: Prentice Hall.

Kommers, D. P. and G. D. Loescher, eds. 1979. Human Rights and American Foreign Policy. Notre Dame, IN: University of Notre Dame Press.

Korean American Voter's Council. Accessed August 13, 2011. http://korean voter.com.

Maki, M. ed. 1999. Achieving the Impossible Dream: How Japanese Americans Obtained Redress. Urbana: University of Illinois Press.

Mansbridge, J. and A. D. Morris. 2001. Oppositional Consciousness: the Subjective Roots of Social Protest. Chicago: University of Chicago Press.

McClain, C. ed. 1994. The Mass Internment of Japanese Americans and the Quest for Legal Redress. New York: Garland.

McPhee, R. D. ed. 2006. The Treatment of Prisoners: Legal, Moral or Criminal? New York: Nova Science Pub Inc.

Morris, A. D. 1984. The Origins of the Civil Rights Movement: Black Communities Organizing for Change. New York: Free Press.

Morris, A. D. 2000. Reflections on Social Movement Theory: Criticisms and Proposals. Comtemporary Sociology 29(3): 445-454.

Morris, A. D. and C. M. Mueller, eds. 1992. Frontiers in Social Movement Theory. New Haven, CT: Yale University Press.

Newcomb, T. M., R. H. Turner, and P. E. Converse. 1965. Social Psychology: The Study of Human Interaction. New York: Holt, Rinehart and Winston.

Niiya, B. ed. 2001. Encyclopedia of Japanese American History: An A-to-Z Reference from 1868 to the Present. New York: Facts on File.

No Comfort. 2007. Editorial. The New York Times. March 6. Accessed August 16, 2011. http://www.nytimes.com/2007/03/06/opinion/06tues3.

Onishi, N. 2007. Abe Rejects Japan's Files on War Sex. The New York Times. March 2. Accessed August 16, 2011. http://www. nytimes.com/2007/03/02/ world/asia/02japan.html.

Park, A. 2007. Seminar with Korean Americans in Virginia.

Raphael, D. D., ed. 1967. Political Theory and the Rights of Man. Bloomington: Indiana University Press.

Rich, W. C. ed. 1996. The Politics of Minority Coalitions: Race, Ethnicity, and Shared Uncertainties. Westport, CT: Praeger.

Roh, H.-D. 2011. Government Proposes Bilateral Meeting to Japan on Comfort Women. Yonhap News. Accessed September 28, 2011, http://engsales.yonha pnews.co.kr/YNA/ContentsSales/EngSales/YISW_PopupMpicPreview.aspx?CI D = MYH20110916003900345.

Ross, R. S. 2000. The 1995-1996 Taiwan Strait Confrontation: Coercion, Credibility, and the Use of Force. International Security 25(2): 87-123.

Ryu, J.-H. 2007. US House of Representative Unanimously Passed the H. Res. 121. The Hankyoreh Daily. July 31. Translated by the author. Last modified. 
Accessed August 7, 2011. http://www.hani.co.kr/arti/international/america/22 6088.heml.

Sassen, S. ed. 2002. Global Networks, Linked Cities. New York: Routledge. Shea, Daniel E. and Michael John Burton. 2006. Campaign Craft: The Strategies, Tactics, and Art of Political Campaign Management. $3^{\text {rd }}$ ed. Westport, CT: Praeger.

Sheng, L. 2001. China's Dilemma: The Taiwan Issue, Singapore: Institure of Southeast Asian Studies.

Shimabukuro, R. S, 2001. Born in Seattle: The Campaign for Japanese American Redress. Seattle: The University of Washington Press.

Shinzo Abe's Double Talk. 2007. Editorial. The Washington Post. Accessed August 16, 2011. http://www.washingtonpost.com/wp-dyn/content/article/ 2007/03/23/AR2007032301640.html.

Son, W.-J. 2011. S. Korea Officially Raises 'Comfort Women' Issue at U. N. The Hankyoreh Daily. October 13. Accessed October 21, 2011. http://english.ha ni.co.kr/arti/english_edition/e_national/500551.html.

Stetz, M. and B. B. C. Oh, eds. 2001. Legacies of the comfort women of World War II. Armonk, NY: M.E. Sharpe.

Takezawa, Y. I. 1995. Breaking the Silence: Redress and Japanese American Ethnicity. Ithaca, NY: Cornell University Press.

The Truth about Japan's 'Comfort Women.' 2007. The Washington Times. Accessed August 16, 2011. http://www.washingtontimes.com/news/2007/apr/ 25/20070425-092608-3474r/.

Turner, R. H. 1957. Collective Behavior. Englewood Cliffs, NJ: Prentice-Hall. Turner, R. H. ed. 1967. Robert E. Park on Social Control and Collective Behavior. Chicago, IL: The University of Chicago Press,

Views and News. 2011. http://www.viewsnnews.com.

Washington Coalition for Comfort Women Issues. 2011. http://www.comfortwomen.org.

Yamazaki, J. W. 2006. Japanese Apologies for World War II: A Rhetorical Study, London: Routledge.

9500 Liberty. 2011. http://www.youtube.com/9500Liberty. 


\section{ENDNOTES}

'Kim, D.-S. 2009. Interview with the author.

The video clip is available at, http://youtube.com/watch?v=v_dOwrAjM_Q.

Kim, D.-S. 2009. Interview with the author. Kim, D.-S. 2011. E-mail interview with the author.

Kim, D.-S. 2009. Interview with the author.

'Huh, I.-H. 2007. Interview with the author.

Kim, D.-S. 2009, Interview with the author.

Ibid.

lbid.

Huh, 1.-H. 2007. Interview with the author.

iv You can watch her and her colleagues' recent activities on this project by following this link: http://www.youtube.com/9500Liberty. 